\title{
Orthodontic intrusion treatment of mandibular anterior teeth in a periodontal patient with hyperdivergent skeletal pattern: 8-year follow-up
}

\author{
Eun-Young Kwon', Kyung-Hwa Jung', Soo-Byung Park³, Seong-sik Kim³, Yong-il Kim³, \\ Youn-kyung Choi ${ }^{1,2 *}$ \\ 'Dental Clinic Center, Pusan National University Hosptial, Busan, Republic of Korea \\ 2(Bio)medical Research Institute, Pusan National University Hospital, Busan, Republic of Korea \\ ${ }^{3}$ Department of Orthodontics, School of Dentistry, Pusan National University, Yangsan, Republic of Korea
}

Patients who have extruded anterior teeth and deep bite with pathologic tooth migration, it is necessary not only periodontal treatment for reduce inflammation, but also orthodontic treatment for intrusion of anterior teeth. However, it is difficult to place the orthodontic brackets due to the deep bite, and there is a problem that the extrusion of the posterior teeth occurs more easily than the intrusion of the anterior teeth biomechanically. In particular, in patients with long face, relative intrusion of the anterior teeth by extrusion of the posterior teeth causes the clockwise rotation of the mandible and makes the facial profile worse. Therefore the biomechanical consideration and appliance design that can block these problems are required from the treatment plan. This is a patient who had a deep overbite with extruded anterior teeth, treated by periodontal treatment and intrusion of mandibular anterior teeth using cute brackes and miniscrews, and resulted in favorable maintenance during 8-year retention. (J Dent Rehabil Appl Sci 2021;37(1):48-60)

Key words: periodontitis; tooth intrusion; deep bite; orthodontic anchorage

\section{서론}

교정 치료에 대한 환자들의 이해와 인식이 높아지면 서 교정 치료를 받는 성인 환자 역시 증가하고 있다. 성인 환자 중, 특히 치주 질환이 호발하는 중장년층에서는, 전 치부 치아의 정출, 총생(crowding)이나 공극(spacing) 등 의 공간 문제가 흔히 관찰되는 대표적인 주소이며, ${ }^{1}$ 이의 개선을 위해 교정 치료를 원하는 경우가 많다. 이러한 증 상은 주로 치주 질환으로 인한 치조골의 소실로 야기되 며, ${ }^{2}$ 치주낭 내 염증세포에서 발생된 압력이 치주 인대에

${ }^{*}$ Correspondence to: Youn-kyung Choi

Clinical Associate Professor, Dental Clinic Center \& (Bio)medical Research Institute, Pusan National University Hospital, 179 Gudeok-ro, Seo-gu, Busan-si, 49241, Republic of Korea

Tel: +82-51-240-7430, Fax: +82-51-240-7706, E-mail: youngyng@hanmail.net Received: January 14, 2020/Last Revision: February 21, 2021/Accepted: February 23, 2021
영향을 끼쳐 나타난다고 알려져 있다. ${ }^{3}$ 치주 질환을 가진 환자들에서는 전치부 총생 혹은 공극이 발생하기도 하지 만, 전치부의 불규칙함이 심해지면서 구강 관리가 어려워 져 치주 질환이 더욱 악화되기 쉬운 환경이 되기때문에, 장기적 치주 관리를 위해서 교정 치료가 추천되기도 한 다.

그러나, 치주 질환으로 인한 치조골의 상실은 교정 치 료를 어렵게 하는 요인이 되기도 하는데, 치주 질환이 조 절되지 않는 상태에서 교정 치료를 시행할 경우, 치조골 의 소실이 가속화될 수 있으며, ${ }^{3}$ 치아의 저항 중심의 변 
화와 고정원의 약화 등으로 교정치료 시 생역학적인 측 면에서도 더욱 고려해야할 사항들이 많아지기 때문이다. 하지만, 치주 질환이 조절되고 있는 상태라면, 비록 치조 골 상실량이 많을지라도 교정치료의 금기증이 되지 않는 다. ${ }^{4}$

전치부의 치조골 소실이 진행된 경우, 상악 전치는 전 방으로 뻐드러지고 정출되어 수직 피개가 깊어지고, 하 악 전치에서는 정출과 총생이 발생하여 교합이 깊어지는 경우가 많다. 따라서 심한 치주적 문제를 보이는 환자의 치료에서는 반드시 전치의 압하가 계획되어야 하며, 치 료 계획에서부터 이를 고려해야 한다. 상하악 전치에서 의 압하가 동반되지 않는 전치의 후방 이동은 종종 상하 악 전치간 교합 접촉을 일으켜, 계획한 치료 목표가 달성 되기 어렵다.

그러나 치주 질환을 가지는 성인 과개 교합 환자에서 의 치료는 몇 가지 추가적인 고려 사항이 있다. 우선 성인 과개 교합 환자에서 전치의 절대적인 압하를 시행할 것 인지, 구치의 교합 거상에 의해 과개 교합을 개선할 것인 지에 대한 진단이 필요하다. 이는 측모에 대한 심미적인 평가와 안정시의 상악 전치 노출도 등에 대한 평가가 요 구되는데, 구치의 교합 거상은 하안모의 수직 고경을 증 가시키고, 하악각을 커지게 하여 하악골의 시계방향 회 전을 야기하기 때문이다. 결과적으로 얼굴이 더욱 길어지 고, 하악의 상대적인 후퇴가 일어난다. 이는 짧은 수직 고 경을 보이는 단안모 환자에서는 양호할 수 있으나, 긴 수 직 고경을 보이는 환자에서는 안모를 더욱 악화시킬 수 있기 때문에 유의해야 한다. 따라서 수직 고경이 긴 환자 에서는 구치의 교합 거상이 아닌 전치의 압하에 따른 과 개 교합의 개선이 시도될 수 있다.

실제 임상에서 전체 악궁에 부착된 고정식 고정장치에 결찰되는 연속되는 호선은 개개 치아에 적용되는 힘에 의한 작용과 반작용에 따라 절대적인 구치의 교합 거상 (상대적인 전치 압하)이나 절대적인 전치의 압하를 달성 하기 어려우며, 여러 종류의 치아 이동이 동시에 발생한 다. ${ }^{5}$ 따라서 절대적인 전치의 압하를 통한 과개 교합이 개 선이 요구된다면 치료 계획 단계에서부터 장치, 역학 등 을 잘 고려하여 조절하는 것이 필요하다. 이를 위해서는 호선을 모든 치아에 결찰하지 않고, 정출된 전치부만 따 로 배열하는 분절호선 방법과 미니스크류 등의 골성 고 정원(Temporary anchorage devices, TADs)을 사용하여 구치 정출에 대한 반작용을 효과적으로 차단하는 방법이 사용될 수 있다.
본 증례는 중등도의 치주염을 보이는 골격성 II급 장안 모의 부정 교합 환자로서, 전반적인 치조골의 소실과 함 께, 정출된 상하악 전치로 인한 과개 교합과 하악 전치 총 생을 보이는 환자이다. 환자는 치료 전, 철저한 치주치료 를 통해서 염증을 조절하였고, II급 장안모 부정 교합의 악화를 차단하기 위해 골성 고정원을 이용하여 하악 전 치의 효율적인 압하가 이루져, 성공적인 치주-교정 치료 결과를 보였다. 이후 8 년간의 유지기간에서도 치주조직 이 건강하게 잘 유지되어 좋은 결과를 보였으므로 이를 보고하는 바이다.

\section{증례보고}

“잇몸이 내려갔어요. 아랫니도 솟구친 것 같아요"를 주소로 교정과로 내원한 30세 여성 환자분이다. 구강 내 임상 소견상, 상하악 전치의 치은 퇴축과 치간 유두 함몰 이 관찰되었으며, 치주낭 탐침 시, 출혈과 치주낭 깊이가 $5 \mathrm{~mm}$ 이상이었다. 하악 전치는 1도 이상의 동요도가 있 었고, 치주낭 깊이가 $6 \mathrm{~mm}$ 이상이었다.

상하악 전치가 정출되어 수직피개 $6 \mathrm{~mm}$ 의 과개 교합 이었고, 특히 상악 중절치는 측절치와 비교해 절단연에서 $1.5 \mathrm{~mm}$ 정출되었으며, 중절치간의 접촉점이 치은연 $1 / 3$ 부위에 위치하여 치간 유두 형태가 불량하다. 또한 상하 악 전치의 치간골 소실로 큰 치간 공극(Black triangle)이 나타났다. 정출에 따른 상하악 전치에서 편평하고 꺼진 전치 치은연이 관찰되어 비심미적이다. 그 외 상악 우측 제 1 대구치와 좌측 제 1 소구치의 보존 및 보철 치료가 필 요한 상태였다.

구강 외 소견상, 하안모가 후퇴된 골격성 II급 부정교 합(SNA : 81.2 $, \mathrm{SNB}: 75.9^{\circ}, \mathrm{ANB}: 5.25^{\circ}$ )을 보였으나, 구순돌출감과 비순각의 경사가 심하지는 않다. 안모의 수직 고경이 긴 장안모(FMA : $35.6^{\circ}$ )의 양상을 띄고 있 으며 정출된 상악 전치와 상대적으로 짧은 상순으로 구 순폐쇄부전과 미소 시 치은 노출도가 크다(Fig. 1).

임상 검사와 마찬가지로 파노라마 방사선 사진에서도, 상하악 전치부에서 중등도의 치조골 흡수가 관찰되고, 특히 상악 좌측 중절치는 원심면에서 깊은 수직적 골결 손과 인접한 치간골 소실이 관찰되었다. 이는 치근단 방 사선 사진을 통해서도 명확히 확인할 수 있는데, 상악 좌 측 중절치 원심면과 하악 전치 사이의 치조골은 치근단 $1 / 2$ - 2/3까지 소실된 상태였으며 치조 백선이 관찰되지 않았다. 상악 중절치와 하악 전치들의 정출이 심하였다. 

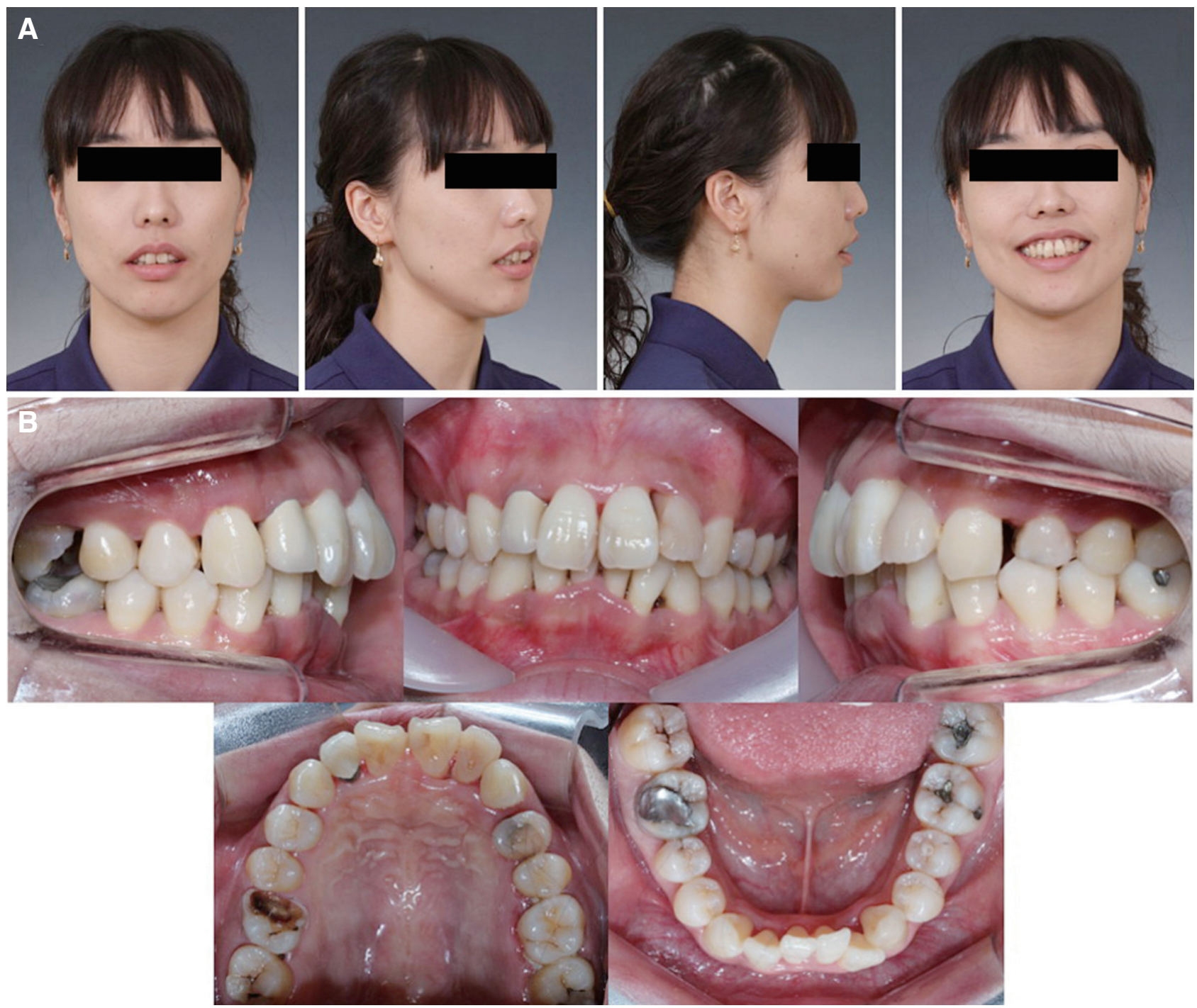

Fig. 1. (A) Pretreatment extraoral photographs. Gummy smile and excessive tooth exposure were observed. (B) Pretreatment intraoral photographs. Deep bite and gingival recession were observed.

또한 상하악 전치부는 불규칙한 치아 배열로 인한 평행 한 치근 배열을 보이지 않고, 치근 사이의 공간이 근접하 여 양형의 치간골 형성이 되지 않아, 치간골 소실이 관찰 되며, 이로 인한 비심미적 치간 공극(black triangle)이 나 타난다.

측모 두부규격 방사선 사진 분석에서, 하악이 후퇴된 골격성 II급 부정교합을 보였으며, 상하악 절치의 각도는 양호하였으나, 수평피개 $(7 \mathrm{~mm})$ 및 수직피개 $(6 \mathrm{~mm})$ 가 크다. 장안모의 Hyperdivegent한 골격 형태를 보이고 있 음을 알 수 있다(Fig. 2).

이에 중등도 만성 치주염으로 진단하고, 우선 치주과 에서 비외과적 치주 치료인 치석 제거술 및 치근 활택술 을 전악에 시행하기로 하였다. 비외과적 치주 치료 완료
후 3 개월의 경과 관찰 후, 정출된 상하악 전치를 비롯한 교합 개선을 위한 교정치료를 진행하기로 하였다. 교정 치료 중에는 3 개월마다 치주과에서 유지 관리를 받기로 동의하여 치료를 진행하였다.

환자 치료의 포괄적인 목표는 먼저 치주 상태를 개선 하여 병적 요소를 제거하고, 치주 조직을 건강한 상태로 회복하며, 이후 교정치료를 통해 병적 이동이 나타난 정 출된 상하악 전치를 배열하여 심미성 및 기능을 개선하 는 것이다.

정출되고 총생을 보이는 상하악 전치를 교정 치료함에 있어, 현재 상악 전치의 임상 치관 길이가 길고, 미소 시 상악 치아 및 치은 노출도가 크며, 하악 후퇴를 보이는 긴 수직 고경의 장안모 환자라는 점을 고려해야했다. 왜 


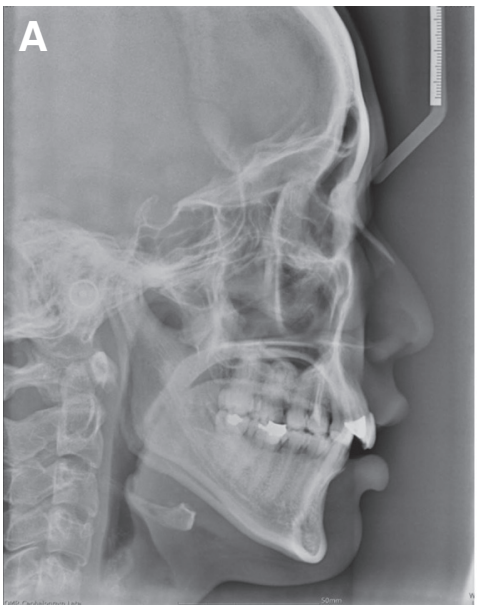

$\begin{array}{lcc} & \text { Mean } & \text { Post-tx } \\ \text { SNA } & 81.6 & 81.2 \\ \text { SNB } & 80.4 & 76.0^{*} \\ \text { ANB } & 2.0 & 5.2^{\star} \\ \text { SN-Mn } & 32.0 & 42.0^{\star *} \\ \text { FMA } & 25.0 & 35.6^{\star *} \\ \text { U1 to SN } & 109.0 & 101.8 \\ \text { IMPA } & 96.5 & 83.3^{*} \\ \text { ANS-ME } & 71.6 & 91.6^{\star *} \\ \text { U1-Stmi } & 1.2 & 6.2^{\star \star} \\ \text { Interlabial gap } & 0.1 & 3.6^{\star} \\ \text { Overjet } & 2.0 & 7.0^{\star *} \\ \text { Overbite } & 2.5 & 6.0^{\star}\end{array}$

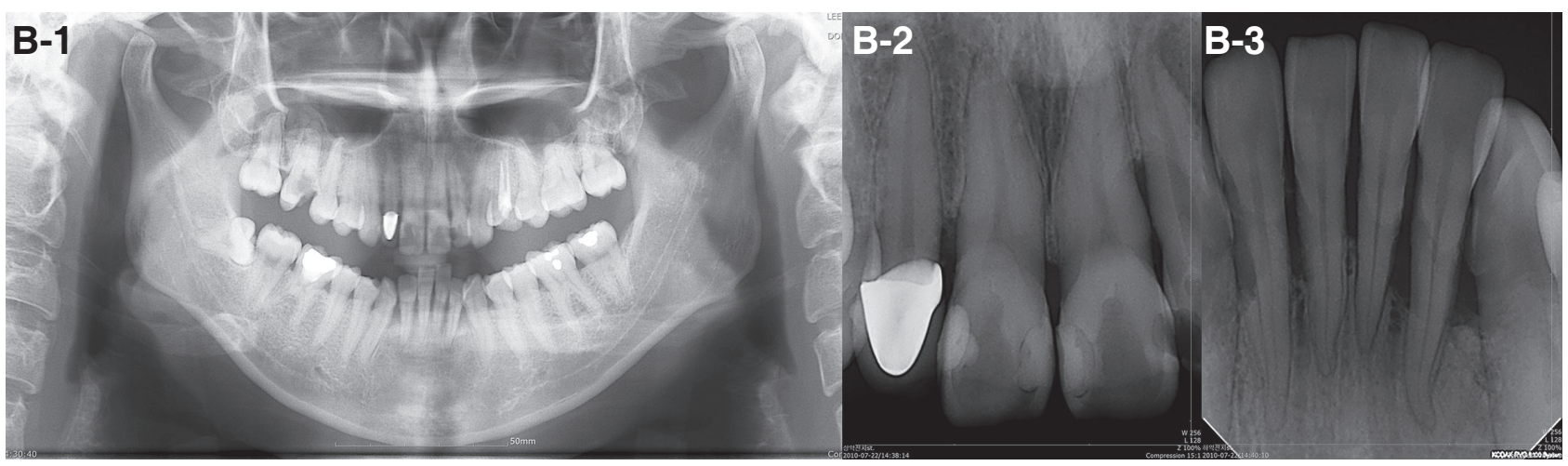

Fig. 2. (A) Pretreatment lateral cephalometric radiograph and analysis. Deep overbite and large overjet were observed. SNA, the angle of sella-nasion-A point; SNB, the angle of sella-nasion-B point; ANB, the angle of A point-nasion-B point; SN-Mn., the angle of SN plane and mandibular plane; FMA, Frankfort mandibular plane angle; U1 to SN, the angle of the long axis of maxillary central incisors between sella-nasion plane; IMPA, the angle of the lowermost tangent to the mandible and the long axis of mandibular incisors; U1-Stmi, the distance of the U1 incisal edge to stomion of upper lip; Interlabial gap, the distance of the stomion of upper lip to lower lip; Overjet, the anterior-posterior distance of the maxillary central incisors over the mandibular central incisors; Overbite, the vertical overlap of the maxillary central incisors over the mandibular central incisors. (B) Pretreatment panoramic (1) \& periapical radiographs (2, 3). Angular alveolar bone loss was observed on the distal root surface of \# 21. Generalized alveolar bone loss was also observed on the mandibular anterior teeth.

$*, * *, * * *$, indicates that the value is beyond one, two or three times of the standard deviation.

냐하면 구치 교합 거상에 의해 과개 교합을 치료할 경우, 하악 치아의 노출도가 증가하며, 하악골이 시계방향 회 전되어 얼굴이 길어지고 하악골이 후퇴되어 안모가 악화 될 수 있기 때문이다. 이에 구치 정출에 의한 교합 변화를 최대한 차단하며, 절대적인 하악 전치 압하를 시행하는 것을 목표로 하였다.

과개 교합이 심한 경우, 하악 전치 순면에 고정식 교 정 장치를 부착할 수 있는 공간이 부족하여 장치의 잦은 탈락이 발생하거나, 이를 피하기 위한 교합 거상판(bite plate)을 사용하게 된다면원치 않는 구치 정출이라는 부 작용이 함께 나타날 수 있다. 따라서 일반적인 고정식 교
정장치보다 작은 미니튜브형태의 교정 장치를 초기 단계 에서 사용하기로 계획하여, 장치의 탈락을 최대한 방지 하고자 하였다.

또한 전악에 부착하는 고정식 교정장치와 연속 호선을 사용할 경우, 압하보다는 정출이 더욱 쉽게 일어나며, 이 에 따라 전치의 상대적인 압하와 더불어 구치의 정출이 반작용으로 나타나므로, 치료 목표를 온전히 달성하기 어렵다. 따라서 본 환자에서는 하악 전치의 최대한의 압 하 효과를 위해 하악에서는 골성 고정원으로 간접 고정 원을 보강하여 전치 압하를 계획하였다.

환자의 만성적인 치주 염증 조절을 위해 치주과에서 전 
반적인 검사를 시행하고, 치은 연하 소파술과 치근 활택 술을 시행하였다. 3 개월 후, 유지 관리 시행하였고, 특별 한 치주적 병적 소견이 관찰되지 않아 교정치료를 시작 하기로 하였다. 교정 치료 시작 후에도, 교정과 내원 3 개 월마다 치주과에서 유지, 관리를 함께 시행하였다. 치아 우식이 존재하는 상악 우측 제 1 대구치는 교정 치료 전 치 료하였다.

상악 치열에는 Roth prescription, $0.022 \times 0.026$-inch slot의 브라켓 (Damon3, Ormco, Orange, USA)을 우 측 제 2 대구치부터 좌측 제 2 대구치까지 부착하고, 0.013inch thermoactive NiTi (Damon, Ormco)호선을 장착하 여 레벨링을 시작하였다. 정출되고, 비심미적인 치은연과 절단연을 보이는 상악 좌우측 중절치는 브라켓을 측절치 보다 $0.5 \mathrm{~mm}$ 절단연으로 위치시켜 상대적인 압하를 통해 심미적 개선을 도모하였다.
하악 치열에서는 좌우 제1소구치 후방에 골성 고정 원(diameter, $1.6 \mathrm{~mm}$; length, $6.0 \mathrm{~mm}$, Jeil Medical Co., Seoul, Korea)을 식립하고, 골성 고정원과 제 1 소구치를 $0.017 \times 0.025$ stainless-steel wire로 고정하여 제 1 소구치 를 수직적 위치 변화가 없는 절대적인 고정원으로 사용 하기로 하였다. 하악 전치의 정출로 하악 전치 순측에 장 치를 부착할 수 있는 공간이 없었으므로, 하악 우측 견 치에서 좌측 견치까지 0.018-inch cute bracket (closed type, HT Co., Ltd., Ansan, Korea)를 부착하고, 0.013inch thermoactive NiTi (Damon, Ormco) 와이어를 장 착하여, 고정원인 제 1 소구치 레벨에 맞추어 하악 전치 압 하를 도모하였다. 구치에는 장치를 부착하지 않아, 구 치 교합을 유지하고 구치 정출을 막고자 하였다. 장치 부착 시에는 과개 교합으로 하악 전치부에 부착된 cute bracket이 관찰되지 않는다(Fig. 3A).

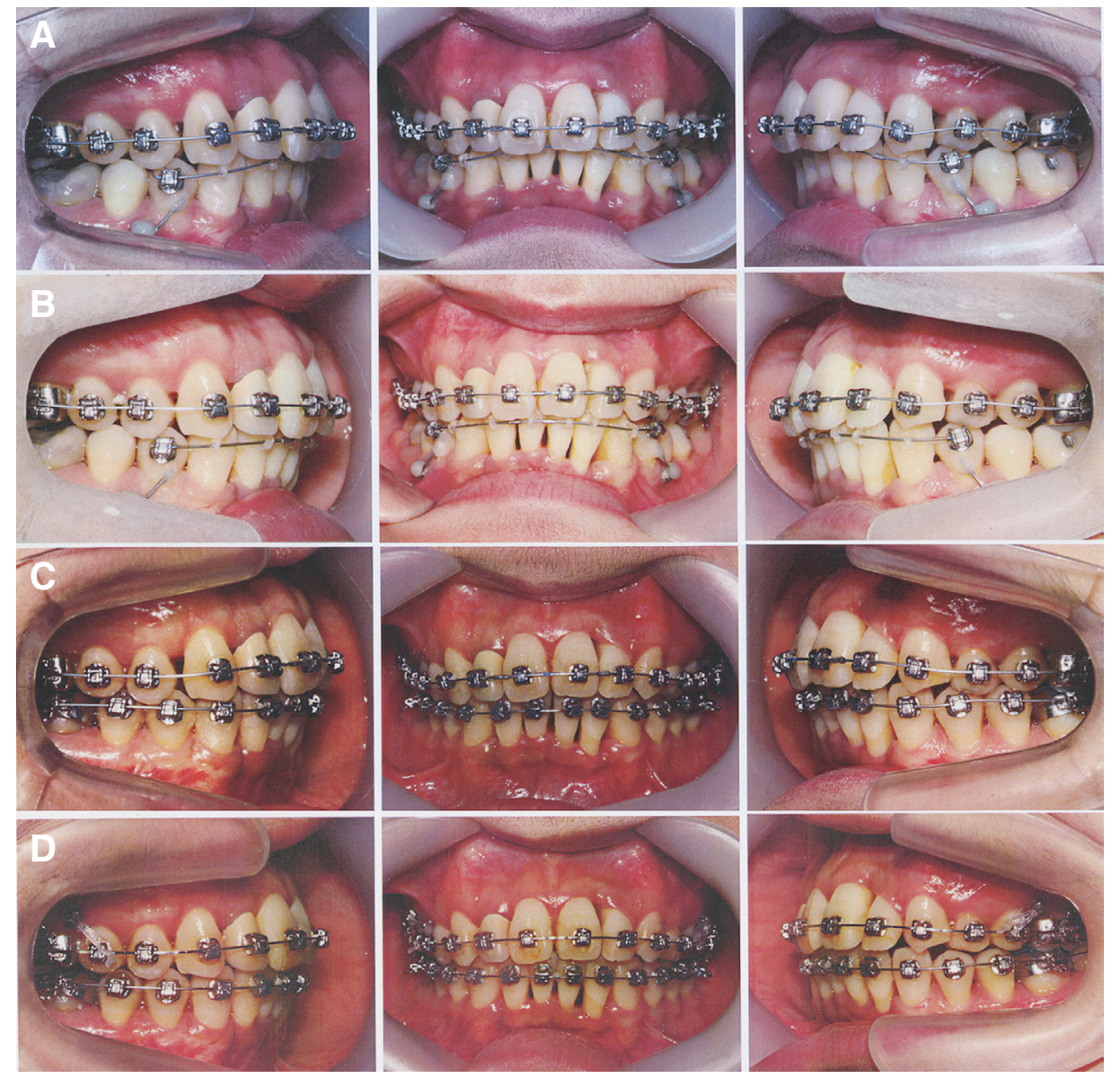

Fig. 3. Intraoral photos during orthodontic treatment. (A) Brackets (maxillary full arch) and cute brackets (mandibular anterior teeth) were bonded. Anchorage preparations were done using temporary anchorage devices(TADs) on mandible. (B - D) Progression of orthodontic treatment. (during 18 months). (B) Overbite was improved. (D) Vertical positions on maxillary arch were maintained using TADs. 
이후 상악에서는 0.016-inch NiTi, $0.016 \times 0.022$-inch $\mathrm{NiTi}, 0.016 \times 0.022$-inch SS 호선을 순차적으로 증가시 켜 레벨링을 지속하였다.

치료를 시작하고 7개월정도 후, 하악에서 cute bracket 이 드러날 정도로 하악 전치부가 레벨링이 되고 고정식 장치를 부착할 수 있을 정도의 수직 피개가 개선되었다. 이에 하악 전치의 압하가 달성되었다고 판단하고, 보다 정교한 개선 및 교합 형성을 위해 하악에도 구치부까지 전체적인 고정식 교정 장치(Damon3, Ormco)로 교체하
여 부착하였다(Fig. 3B, 3C).

통상적인 교정치료를 통해 상악 견치 후방에 존재하는 공극을 폐쇄하고, 상하악간의 양호한 전치부 수직, 수평 피개 및 구치부 교합이 관찰되어 1년 6개월 후, 교정 장치 를 제거하였다. 상악에서는 가철성 유지장치를 제작하였 으며, 하악은 견치-견치간 고정식 보정장치를 부착하였 다. 전체 교정치료 기간은 25 개월이었다. 교정치료 후, 상 악 좌측 제1소구치 및 상하악 우측 제1대구치 보철 수복 으로 구강회복을 시행하여 마무리하였다(Fig. 4A).
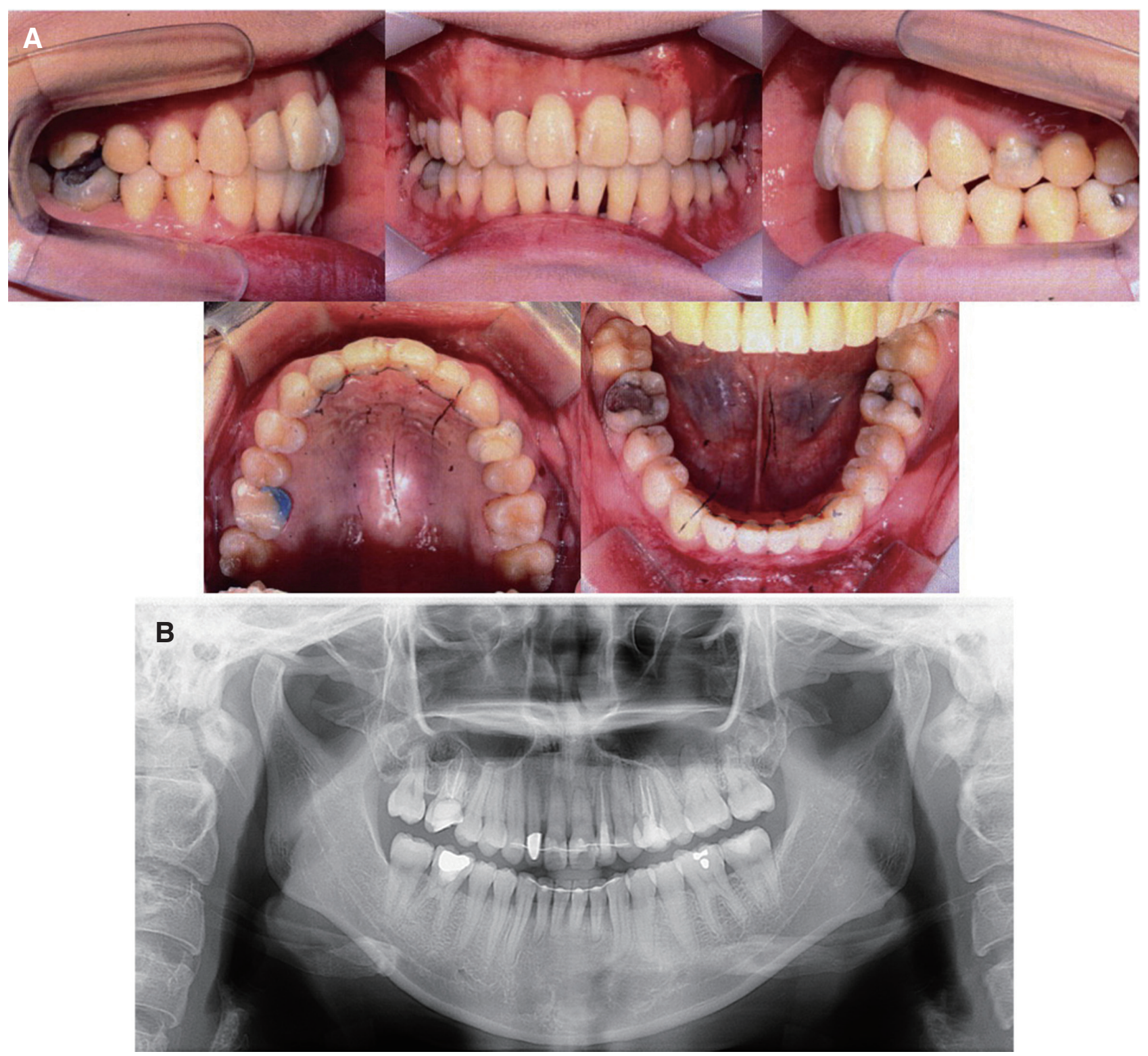

Fig. 4. Posttreatment intraoral photographs (A) and panoramic radiograph (B). Normal overbite and overjet were achieved. Fixed retainer was placed on both anterior teeth. 
이후 8년간 치주과와 교정과에서 주기적으로 유지 관 리를 시행하였다.

치주 치료와 교정 치료로 치주 조직의 염증이 개선되 고, 정출된 상하악 전치의 위치 개선을 통해 보다 나은 구 강 환경과 심미성을 달성하였다. 상악에서는 좌우측 중 절치가 상대적으로 압하되어, 심미적인 상악 치열과 치은 연의 조화를 보였으며, 상악 전치의 절단연이 미소선과 조화를 이루게 되었다. 상하악 전치간 교합은 수직 피개, 수평 피개 모두 $2 \mathrm{~mm}$ 로 개선되었다. 상하악 전치간 각 도 및 견치/구치 관계 역시 양호하다(Interincisal angle: $\left.127.3^{\circ}\right)$.

이는 하악 절치의 절대적인 압하와 순측 경사에 의한 것으로 판단된다. 측모 두부 방사선 사진으로 치료 전/ 후 중첩 평가 시, 이를 확인할 수 있는데, 하악 제 1 소구 치 부위에 식립한 골성 고정원을 절대 고정원으로 삼아, 하악 구치의 정출은 나타나지 않고, 하악 절치는 압하 및 순측 경사 되었다. 또한 하악골의 시계 방향 회전으로 인 한 안모의 악화는 최소화할 수 있었다(Fig. 5A, 5B).

치주 치료와 교정 치료 이후, 상하악 전치 치근이 평행 하게 배열되고, 치축 개선으로 상악 좌우측 중절치간 접 촉점이 좀 더 절단연측으로 이동하였으며, 치간골과 함 몰되었던 치간 유두의 수직 위치가 개선되어 보다 심미적 이다. 치간 공극(black triangle) 역시 좌측 중절치 원심에 서 크게 개선되어 감소하였다. 전악에서 $3 \mathrm{~mm}$ 이내의 치 주낭 깊이를 보였다. 방사선 사진에서 압하 치료를 하였 음에도 과도한 하악 전치부 치근 흡수는 나타나지 않았 다. 그러나 적극적인 압하력을 가하지 않았던 상악 좌측 중절치의 동요도는 존재하지 않았지만, 치근 흡수 소견 을 보였다(Fig. 4B).

8년간의 유지 관리 기간 동안, 상하악 전치의 수직적 위치는 양호하게 유지되었다. 치주 조직 역시 치주낭 탐 침 시 $3 \mathrm{~mm}$ 이내 깊이로 유지되었으며, 과도한 치은 퇴 축이나 치료 종료시와 비교하여 진행된 치근 흡수 소견 등은 관찰되지 않았다. 하악 전치에서 치조골 소실이 경 과 관찰 기간 동안 치근단 $1 / 2-1 / 3$ 지점에 위치하여 깊 어지지 않았으며, 방사선 사진 상에서 치조백선이 관찰된 다(Fig. 6, 7).

\section{결과 및 고찰}

치주 질환이 있는 환자에서 교정 치료를 시행하는데 있 어서, 교정 치료 그 자체로 치주 조직의 파괴가 가속화되
는 것이 아닌가 하는 의문이 있었다. ${ }^{6}$ 그러나 치주염은 치 주낭 내의 세균성 치태가 그 원인으로, ${ }^{7}$ 치주 치료와 적절 한 구강 위생으로 세균성 치태가 잘 관리되어, 염증이 조 절된다면 교정 치료로 발생하는 치주 조직의 파괴는 가 역적이며, 교정 치료를 시행할 수 있다고 알려져 있다.,8 또한 감소된 치조골로 인한 주의가 필요하나, 이 역시 교 정 치료를 불가능하게 하지 않으며, 교정 치료를 통해서 치주 조건을 오히려 양호하게 개선할 수 있다. ${ }^{9}$ 전치부 치 조골 소실을 보이는 환자들은 정출을 동반한 상악 전치 의 순측 경사와 공극, 하악 전치에서의 총생 등이 흔히 관 찰되므로, 교정 치료를 통해서 치아 배열이 개선될 경우 구강 위생 관리가 오히려 쉬워질 수 있기 때문이다. 교정 장치를 부착하는 시기에 대해서는 치주 치료를 시행하 고 2 - 6개월의 경과 관찰 후에 치주 조직의 리모델링과 회복, 그리고 환자의 유지 치료에 대한 협조도 등을 평가 하여 교정 장치를 부착하는 것을 권하고 있다. ${ }^{10}$ 상기 환 자 역시 상하악 전치부의 치근단 $1 / 2$ 이상의 치조골 소실 을 보인 환자로서, 교정치료 전 전악에 걸친 치은 연하 소 파술과 치근 활택술을 시행하여 염증을 조절하였고, 3 개 월의 유지기간 이후 치은 탐침 시 치주낭의 깊이가 $3 \mathrm{~mm}$ 이하로 개선되고, 출혈이 관찰되지 않아 교정치료를 시 작하였다. 이후에도 3 개월마다 치주과에서 치주 유지 관 리를 시행하였으며 파괴적인 치주 조직 변화가 관찰되지 않았다.

본 증례의 환자에서 교정 치료시 가장 중요하게 고려 된 사항은 과개 교합의 개선이었다. 큰 수직 피개를 보이 는 과개 교합 환자에서 이를 개선하는 데에는 크게 3 가 지의 방법이 있다. ${ }^{4}$ 첫 번째는 성장기 아동에서 하악지의 수직적 성장이 남아있을 때 구치들이 맹출하는 동안, 전 치들을 상대적으로 압하시키는 것이다. 이 경우에는 하 악의 성장이 동반되므로 하악두를 중심으로 한 하악골의 후하방 회전이 관찰되지 않는다. 두 번째는 성인에서 구 치를 정출시켜, 하악골의 후하방 회전을 통해 과개 교합 을 치료하는 방법이며, 마지막 방법은 상하악 전치의 절 대적 압하로, 치근첨을 코와 하악 하연에 가까워지게 하 는 것이다. 성장기 환자와는 달리 성인에서는 하악골의 성장이 동반되지 않으므로, 고정식 교정 장치와 전악에 걸쳐 결찰된 호선으로는 압하보다는 정출에 적합한 최적 의 힘이 적용되기 쉬워, 구치부의 정출, 즉 두 번째 방법의 개선이 더 쉽게 일어난다. 그러나 이러한 두 번째 방법을 통한 개선에서는 추가적으로 상하악골의 전후방적, 수직 적 위치 및 안모를 고려해야 한다. 이는 성장이 없는 성인 


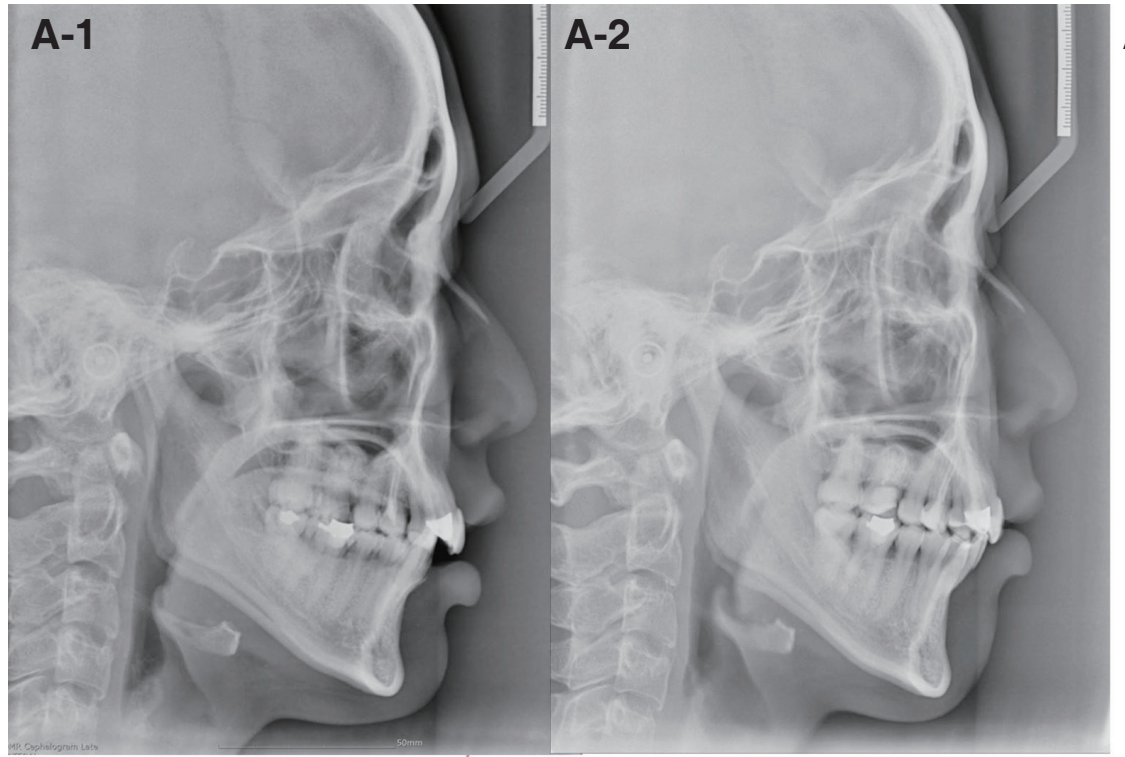

\section{B-1}

Superimposition (Na-Ba line)

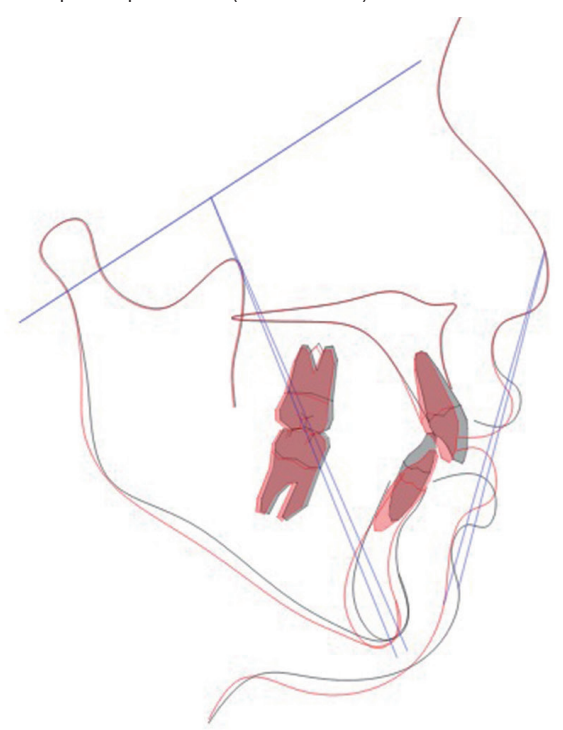

Superimposition (Palatal plane;ANS-PNS)

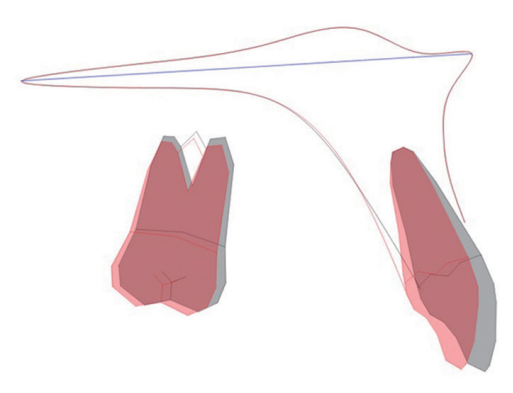

A-3

$\begin{array}{lccc} & \text { Mean } & \text { Post-tx } & \text { Retention } \\ \text { SNA } & 81.6 & 81.2 & 81.2 \\ \text { SNB } & 80.4 & 76.0^{*} & 75.2^{\star} \\ \text { ANB } & 2.0 & 5.2^{*} & 6.0^{\star} \\ \text { SN-Mn } & 32.0 & 42.0^{\star \star} & 42.6^{\star \star} \\ \text { FMA } & 25.0 & 35.6^{\star \star} & 36.3^{\star \star} \\ \text { U1 to SN } & 109.0 & 101.8 & 95.4^{*} \\ \text { IMPA } & 96.5 & 83.3^{*} & 92.9 \\ \text { U1-Stmi } & 1.2 & 6.2^{* *} & 4.8 \\ \text { Interlabial gap } & 0.1 & 3.6^{*} & 1.9 \\ \text { Overjet } & 2.0 & 7.0^{* *} & 2.6 \\ \text { Overbite } & 2.5 & 6.0^{*} & 3.3\end{array}$

\section{B-3}

Superimposition (Xi-Pm line)

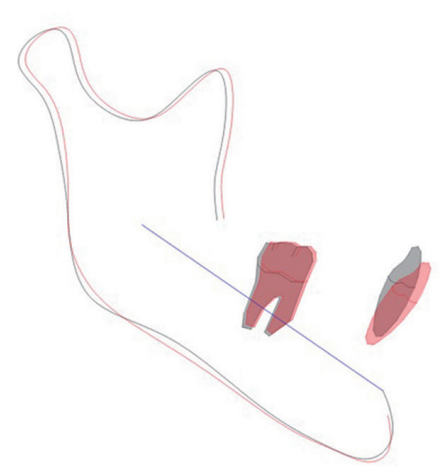

Fig. 5. Pretreatment, posttreatment lateral cephalometric radiographs (A) and superimposition analysis (B). (A) Pretreatment (1), posttreatment (2) radiographs and cephalometric analysis (3). (B) Superimposition of pretreatment and posttreatment. B-1, Superimposition of the maxilla and mandible based on the cranial base (Nasion-Basion line). B-2, Superimposition of the maxilla based on palatal plane (ANS-PNS). B-3, Superimposition of the mandible based on Xi$\mathrm{Pm}$ line (Xi, the point placed in the center of the mandibular ascending ramus; Pm, point where curvature of the anterior contour of the symphysis changes from concave to convex).

During orthodontic treatment, the vertical position of the mandibular posterior teeth was maintained and the mandibular anterior teeth were intruded and labioversion. However, the maxillary molar was mildly extruded during the leveling process, and a slight clockwise rotation of the mandible was observed (gray line: pretreatment, red line: posttreatment).

$*, * *, * * *$, indicates that the value is beyond one, two or three times of the standard deviation. 

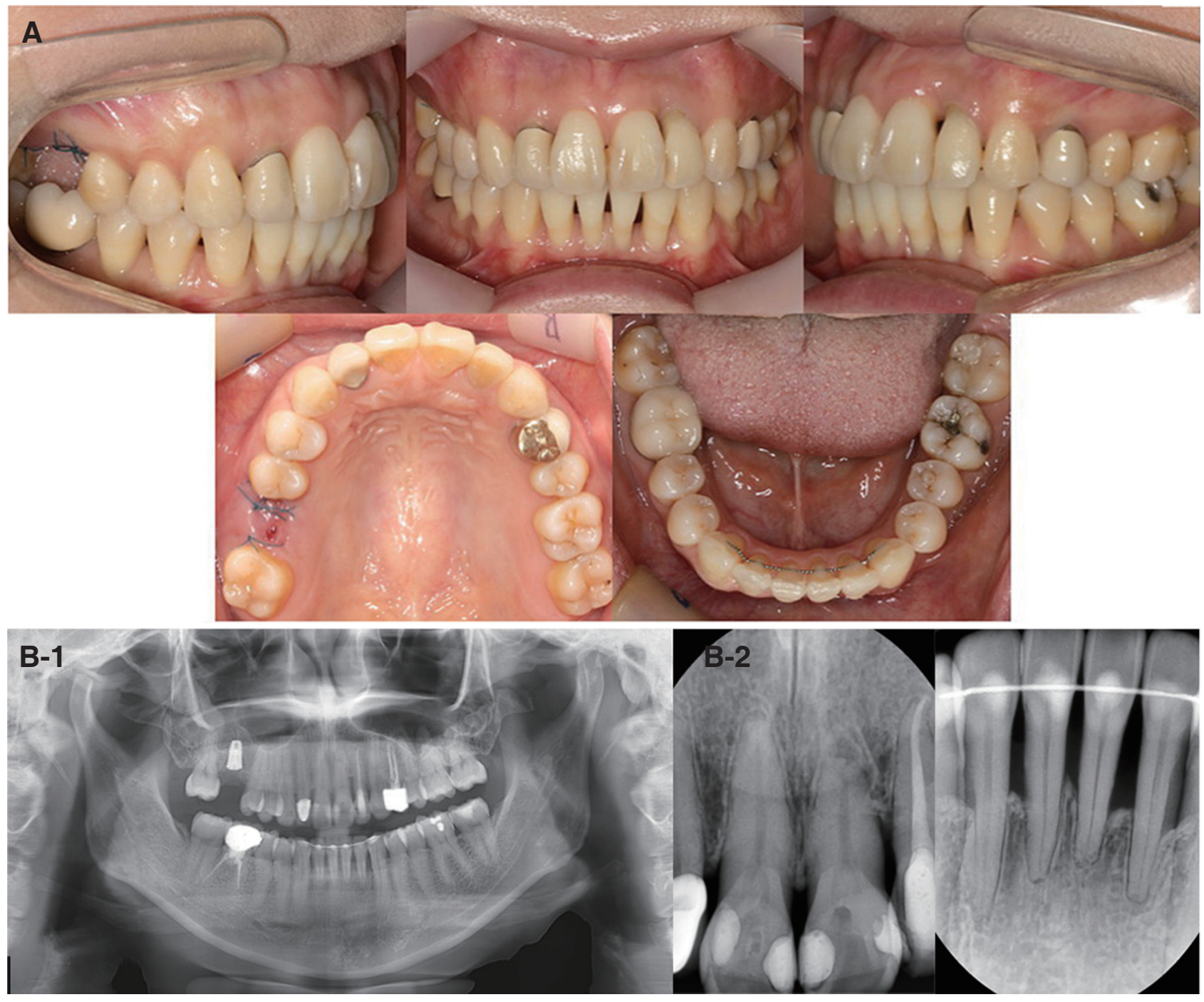

Fig. 6. Intraoral photographs (A) and panoramic \& periapical radiographs (B) for 8-year retention period. Overjet and overbite were maintained. \#16 was extracted. Implant fixture was placed on \#16 site. Lamina dura was observed on periapical radiographs.
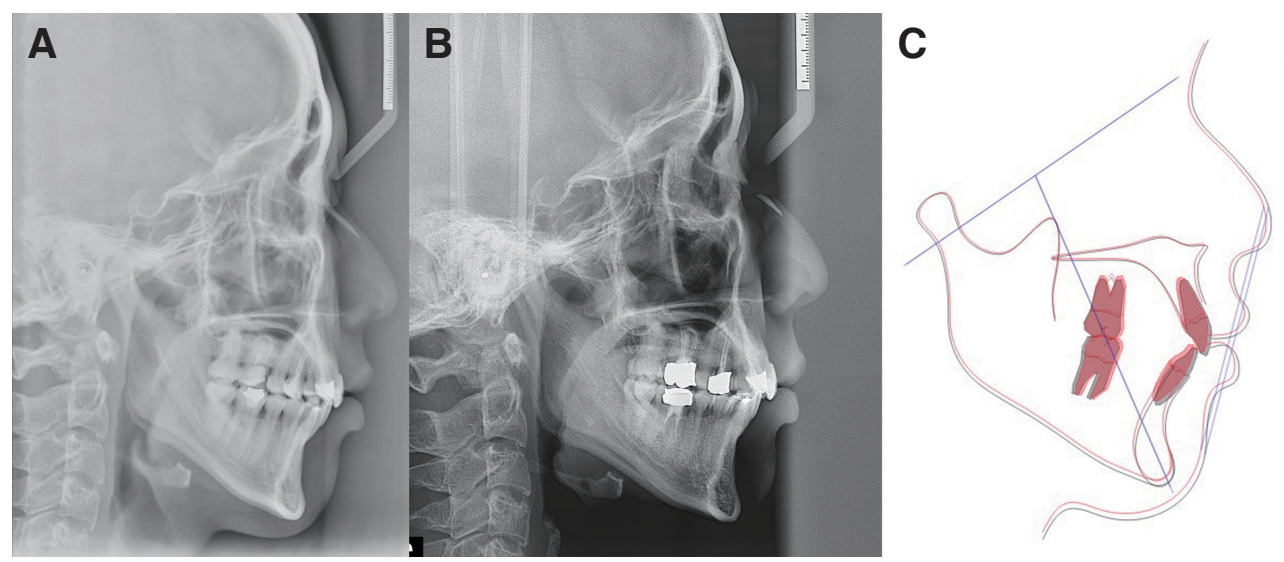

$\begin{array}{lcc}\text { D } & & \\ \text { SNA } & 81.2 & 81.2 \\ \text { SNB } & 75.2^{*} & 75.1^{\star} \\ \text { ANB } & 6.0^{*} & 6.1^{*} \\ \text { SN-Mn } & 42.6^{\star *} & 42.5^{\star *} \\ \text { FMA } & 36.3^{* *} & 36.1^{\star *} \\ \text { U1 to SN } & 95.4^{\star} & 94.3^{*} \\ \text { IMPA } & 92.9 & 92.7 \\ \text { U1-Stmi } & 4.8 & 4.5 \\ \text { Interlabial gap } & 1.9 & 1.5 \\ \text { Overjet } & 2.6 & 2.9 \\ \text { Overbite } & 3.3 & 3.7\end{array}$

Fig. 7. Lateral cephalometric radiograph of posttreatment (A), 5-year follow-up (B), superimposition of $A \& B,(C)$ and analysis (D). 
에서 구치가 정출될 경우, 하악의 시계방향 회전으로 하 악골이 후퇴되고, 수직고경이 길어지기 때문이다. 수직 고경이 짧은 단안모 환자에서는 이를 이용하여 안모를 개선할 수 있으나, 긴 수직 고경의 장안모 환자에서는 심 미적으로 안모가 악화될 수 있다. 상기 환자는 미소 시 치 은 노출도가 크고, 장안모의 수직적 부조화를 보였으며, 하악골이 상대적으로 후방에 위치하여 구순폐쇄부전이 나타났으므로, 추가적인 하악골의 시계방향(후하방) 회 전을 방지하는 것이 필요했다. 이를 위해 세 번째 방법인 절대적인 하악 전치의 압하를 도모하기로 하였다.

골성 고정원을 이용하여 전치 압하를 시행할 때, 대 부분의 경우 골성 고정원에 elastomeric module, coiled spring 및 결찰 호선을 이용하여 직접 힘을 가하는 경우 가 많다. 하악 전치에 이를 적용할 경우, 직접 힘을 가하 기 위해서는 하악 전치 치근 사이에 골성 고정원을 식립 하게 된다. 그러나 하악 전치 치근 사이에 식립된 골성 고 정원은 치근 사이의 공간이 좁아 치근과 근접하므로, 탈 락이 빈번하며, 치근 손상의 가능성이 높아진다. ${ }^{11}$ 또한 이를 피하기 위해 부착 치은이 아닌 아래 점막에 식립할 경우, 노출형으로 식립하면(open method) 하순과 점막 을 자극하여 염증을 일으키는 경우가 많고, 폐쇄형으로 식립 시(closed method) 제거를 위한 추가적인 수술이 필 요하므로, 환자의 불편함이 증대된다. ${ }^{12}$ 이에 본 증례에 서는 골성 고정원에 직접적인 힘을 가하지 않고, 골성 고 정원을 치근 사이 공간이 넓은 하악 소구치 부착 치은 부 위에 식립하여 소구치의 이동을 최소화함으로써 움직이 지 않는 간접 고정원으로 사용하였다. 이를 통해 치근 손 상 가능성과 골성 고정원의 잦은 탈락의 가능성을 줄였 으며, 소구치 부착 치은에 골성 고정원을 위치시켜, 염증 및 점막 자극으로 인한 환자의 불편함 역시 줄일 수 있었 다. 골성 고정원을 간접 고정원으로 이용하여 하악 구치 에 장치를 부착하지 않은 채로, 레벨링 과정을 통해 하악 전치부의 압하를 도모하였다. 이에 하악 구치의 수직적 변화없이 하악 전치가 $1.5 \mathrm{~mm}$ 압하되어 수직 피개가 개 선되었다.

그러나 치주 질환을 가진 환자의 경우, 전치 압하를 위 해 압하력을 가할 경우, 골소실로 인한 치주 인대 영역의 축소로, 치근단에 더 큰 압력이 가해질 수 있다. 이에 과 도한 치근 흡수 등이 나타날 수 있으므로, 보다 적은 힘 을 부여해야 한다. ${ }^{9}$

많은 연구에서 전치 압하 과정과 그 이후 유지 기간 동 안 압하 치아에서 높은 치근 흡수율에 대해 보고 하였
다. ${ }^{13,14}$ 그러나 적절한 힘과 토크 조절을 시행할 경우, 이 러한 부작용을 줄일 수 있다는 연구들 역시 존재한다. ${ }^{15,16}$ 비록 치근이 뭉툭해지는 정도의 흡수(blunting)가 관찰될 수 있으나, 통상적인 교정치료 환자와 비교했을 때 유의 미할 정도의 차이는 아니었다고 보고하였다. 본 증례에 서도 초기 $013 \mathrm{NT}$ 를 이용하여 하악 전치에 압하력을 가 하였으며, 치료 중 하악 전치의 과도한 치근 흡수는 관찰 되지 않았으며, 이는 경과 관찰 기간에도 유지되었다.

만약 교정 치료 전 염증 조절이 되지 않는다면, 치근 흡 수와 비가역적인 치주 조직의 파괴가 나타날 수 있다. 압 하 치료 후 치주 인대의 반응에 대해서, 이상적인 치주 인 대의 재부착이 일어난다는 견해도 있지만, ${ }^{3}$ 재부착이 일 어나지 않고, 압하 방향으로 치아를 이동시켜 치주낭이 깊어지는 부작용을 야기한다는 견해도 있기에, ${ }^{17}$ 세심한 주의가 필요하다. 또한 압하 치료를 시행한 환자에서 치 주 조직의 이동 방향 등에 대해서는 다양한 연구가 있었 다. ${ }^{6,79}$ 압하 치료시, 철저한 치주치료를 시행하고, 조절된 교정력을 적용할 경우, 치아는 압하되어 악골 하연 방향 으로 이동하고, 치조골 변연부는 반대로 치관측으로 이 동한다는 보고가 있으나, ${ }^{6,9}$ 치은연이 압하되는 치아 이 동과 같은 방향으로 $80 \%$ 정도 하방 이동하여, 치아 임 상 치관이 길어진다는 상반된 연구 결과 또한 존재한다. ${ }^{7}$ 본 증례에서는 상악 중절치가 치아 레벨링에 의하여 1.5 $\mathrm{mm}$ 상대적으로 압하되었으나, 치료 종결시 치은연의 위 치는 치아와 함께 상방 이동하지 않고 유지되어 상악 측 절치의 치은연과 조화를 이룬다. 또한 치주낭 탐침 시 깊 이 역시 $3 \mathrm{~mm}$ 이하로 유지되어 치조골 변연부가 상대적 으로 치관측으로 이동된 것으로 판단된다. 8 년의 경과 관 찰 기간 동안에도 치주낭 탐침은 $3 \mathrm{~mm}$ 이내로 유지되었 다. 또한 치료 종결 5 년 후 채득한 측모 두부 방사선 계 측에서, 하악 전치는 $0.4 \mathrm{~mm}$ 정출 및 설측 경사되었으며, 수직 피개가 $0.4 \mathrm{~mm}$ 증가하였으나, 전반적으로 과개 교 합이 재발하지 않고 양호하게 유지되었다(Fig. 7).

치간 유두의 형태와 수직적 위치는 치조골의 형태와 위 치, 인접 치아의 치간 접촉점과 백악법랑경계의 위치 등 에 영향을 받는다. 상기 환자는 특히 상악 전치부 치은이 치조골 소실과 치간 유두의 함몰로, 편평하고 negative gingiva architecture를 보여 비심미적이었다. 따라서 치 주 치료와 레벨링을 통한 상악 전치의 상대적 압하를 시 행하여 치조골의 상대적인 수직 위치가 개선되고, 절치간 치간 접촉점의 위치가 개선되면서 치간 유두의 형태 역시 개선되었다. 
상기 환자와 같이 과개 교합을 보이는 경우에는, 하악 전치 순측에 고정식 교정 장치를 부착하기가 어려운 경 우가 많다. 따라서 본 증례에서는 초기 압하와 레벨링 에 내경이 0.018-inch인 closed type의 cute bracket 장치 를 사용하였다. 이러한 미니튜브 형태의 장치는 일반적 인 $0.022 \times 0.025$-inch 브라켓보다 사이즈가 작아 과개 교합 환자에서 사용하기 용이하며, 결찰을 하지 않으므 로 마찰력이 적어 치주 질환자와 같이 약한 힘의 적용이 필요한 환자에게서 유용하다. ${ }^{18}$ 왜냐하면 치조골이 소실 되면, 치아의 저항 중심이 더욱 치근단 방향으로 이동하 기 때문에 적은 면적의 치주인대에서 상대적으로 단위면 적당 적용되는 힘이 커, 치아가 적은 힘에도 큰 반응을 보 이기 때문이다. ${ }^{9}$ 따라서 보다 약한 힘을 적용하는 것이 중 요하며, 환자가 느끼는 동통이나 불편함 역시 줄어든다. 본 증례에서는 미니튜브 형태의 장치와 0.013-inch thermoactive NiTi를 사용하여 초기 배열에 보다 약한 힘을 적용하였다. 그러나 미니튜브 장치는 브라켓과 비교하여 3 차원적 정교한 치아 이동은 어렵기 때문에 초기 배열과 압하 이후, 일반적인 고정식 교정 장치로 바꿔 부착하는 것이 바람직하다.

치주 환자의 치료에서는 교정 치료 후, 고정식 유지 장 치를 사용하는 것이 필수적이다. 이는 성장기 아동보다 성인에서는 치주 조직의 적응이 오래걸리며, 치주염이 심 했을 경우, 더욱 재발이 클 수 있으므로, ${ }^{19}$ 구강 위생 관리 에 방해가 되지 않는다면, 견치-견치에 고정식 보정장치 를 부착하여 반영구적으로 사용하는 것도 고려되어야 한 다. ${ }^{20}$ 또한 전치 압하에 의해 과개 교합을 치료한 경우, 수 직 피개가 다시 증가하는 보고가 많다. ${ }^{21,22}$ Bernstein 등 은 골성 고정원을 이용하지 않고, 통상적인 교정 치료 방 법으로 호선을 통해 구치를 정출하여 스피 만곡을 개선 한 경우, 하악 전치는 $1.66 \pm 2.3 \mathrm{~mm}$ 재발하여 수직 피개 가 깊어진다고 보고하였다. ${ }^{22}$ 이에 과교 개합 환자의 재 발 방지를 위해서 고정성 유지 장치뿐만 아니라 가철성 유지 장치에 전치부 교합판을 추가하는 것이 도움이 될 수 있다.

\section{결론}

전치부 치조골 소실을 동반한 전치의 정출을 보이는 장안모 환자에서, 교정 치료 전 치주과와 긴밀히 협력한 철저한 치태 관리와 치주 염증의 관리는 무엇보다 중요 하다. 교정 치료 계획 수립시에는 치아 이동에 따른 골격
변화와 함께 안모 변화 등도 고려하여, 세심한 치아 이동 방향을 설계하고, 적절한 장치 선택 역시 치료 전 고려되 어야 한다. 본 증례에서는 전치부 치조골 소실로 인한 상 하악 전치의 정출과 치열의 불규칙이 관찰되었으며, 교정 치료시 구치 정출로 인한 안모 악화라는 반작용을 차단 하기 위한 골성 고정원의 사용과 미니튜브 장치를 이용 한 전치부 부분 교정 장치 디자인으로 효율적인 하악 전 치 압하를 가져올 수 있었다.

\section{Acknowledgement}

본 연구는 2021년도 부산대학교 병원 임상연구비 지원 으로 이루어졌음.

\section{ORCID}

Eun-Young Kwon https://orcid.org/0000-0001-9555-0360 Kyung-Hwa Jung https://orcid.org/0000-0002-8305-0016 Soo-Byung Park https://orcid.org/0000-0002-9774-9178 Seong-sik Kim https://orcid.org/0000-0003-1988-6043

Yong-il Kim https://orcid.org/0000-0003-3889-2545

Youn-kyung Choi https://orcid.org/0000-0003-1491-2986

\section{References}

1. Fukunaga T, Kuroda S, Kurosaka H, TakanoYamamoto T. Skeletal anchorage for orthodontic correction of maxillary protrusion with adult periodontitis. Angle Orthod 2006;76:148-55.

2. Martinez-Canut P, Carrasquer A, Magán R, Lorca A. A study on factors associated with pathologic tooth migration. J Clin Periodontol 1997;24:492-7.

3. Melsen B, Agerbaek N, Eriksen J, Terp S. New attachment through periodontal treatment and orthodontic intrusion. Am J Orthod Dentofacial Orthop 1988;94:104-16.

4. Proffit W, Fields H, Larson B, Sarver D. Contemporary Orthodontic. 6th ed. Elselvier; 2018.

5. Burstone CR. Deep overbite correction by intrusion. Am J Orthod 1977;72:1-22.

6. Thilander B. Orthodontic tooth movement in periodontal therapy. In: Lindhe J. Textbook of Clinical Periodontology. Copenhagen; Munksgaard; 1989. p. 
450-500.

7. Alstad S, Zachrisson BU. Longitudinal study of periodontal condition associated with orthodontic treatment in adolescents. Am J Orthod 1979;76: 277-86.

8. Artun J, Urbye KS. The effect of orthodontic treatment on periodontal bone support in patients with advanced loss of marginal periodontium. Am J Orthod Dentofacial Orthop 1988;93:143-8.

9. Melsen B, Agerbaek N, Markenstam G. Intrusion of incisors in adult patients with marginal bone loss. Am J Orthod 1989;96:232-41.

10. Gkantidis N, Christou P, Topouzelis N. The orthodontic-periodontic interrelationship in integrated treatment challenges: a systematic review. J Oral Rehabil 2010;37:377-90.

11. Kuroda S, Yamada K, Deguchi T, Hashimoto T, Kyung HM, Takona-Yamamoto T. Root proximity is a major factor for screw failure in orthodontic anchorage. Am J Orthod Dentofacial Orthop 2007;131 Suppl 4:S68-73.

12. Kuroda S, Sugawara Y, Deguchi T, Kyung HM, Takona-Yamamoto T. Clinical use of miniscrew implants as orthodontic anchorage: success rates and postoperative discomfort. Am J Orthod Dentofacial Orthop 2007;131:9-15.

13. Baumrind S, Korn EL, Boyd RL. Apical root resorption in orthodontically treated adults. Am J Orthod Dentofacial Orthop 1996;110:311-20.

14. Han G, Huang S, Von den Hoff JW, Zeng X, Kuijpers-Jagtman AM. Root resorption after orthodontic intrusion and extrusion: an intraindividual study. Angle Orthod 2005;75:912-8.

15. Carrillo R, Rossouw PE, Franco PF, Opperman LA, Buschang PH. Intrusion of multiradicular teeth and related root resorption with mini-screw implant anchorage: a radiographic evaluation. Am J Orthod Dentofacial Orthop 2007;132:647-55.

16. Sameshima GT, Sinclair PM. Predicting and preventing root resorption: part II. Treatment factors. Am J Orthod Dentofacial Orthop 2001;119:511-5.

17. Erkan M, Pikdoken L, Usumez S. Gingival response to mandibular incisor intrusion. Am J Orthod Dentofacial Orthop 2007;132:143.e9-13.

18. Hwang HS, Jeon HR, Kim SP, Kim WS, Lee GH.
A new orthodontic appliance for rapid anterior alignment in adults: Mini-tube appliance (MTA). J Korean Dent Assoc 2011;49:334-45.

19. Ericsson I, Thilander B. Orthodontic relapse in dentitions with reduced periodontal support: an experimental study in dogs. Eur J Orthod 1980;2:517.

20. Alexander RG. Treatment and retention for longterm stability. In: Nanda R, Burstone CJ, eds. Retention and stability in orthodontics. Seoul; DaehanNarae Publishing Inc.; 1996. p. 113-23.

21. Al-Buraiki H, Sadowsky C, Schneider B. The effectiveness and long-term stability of overbite correction with incisor intrusion mechanics. Am J Orthod Dentofacial Orthop 2005;127:47-55.

22. Bernstein RL, Preston CB, Lampasso J. Leveling the curve of Spee with a continuous archwire technique: a long-term cephalometric study. Am J Orthod Dentofacial Orthop 2007;131:363-71. 


\section{장안모를 보이는 치주 질환자에서 하악 전치의 압하를 통한 과개 교합 치료: 8년 경과 관찰}

권은영 ${ }^{1}$ 임상부교수, 정경화 ${ }^{1}$ 임상부교수, 박수병 ${ }^{3}$ 교수, 김성식 ${ }^{3}$ 교수, 김용일 ${ }^{3}$ 부교수, 최윤경 ${ }^{1,2 *}$ 임상부교수

${ }^{1}$ 부산대학교병원 치과진료센터

${ }^{2}$ 부산대학교병원 의생명연구소

${ }^{3}$ 부산대학교 치의학전문대학원 치과교정과

치아의 병적 이동으로 전치가 정출되고 수직 피개가 깊은 치주염 환자에서는 치주 염증 치료와 더불어 정출된 전치의 위 치 개선이 필요하다. 그러나 깊은 수직 피개로 교정 장치 부착이 어렵고, 역학적으로 전치 압하보다 구치 정출이 더욱 쉽 게 발생하는 문제점이 있다. 특히 골격적 장안모를 보이는 환자에서 구치 정출을 통한 상대적 전치 압하는 안모의 악화 를 야기하므로, 치료 계획에서부터 이를 차단하기 위한 설계가 필요하다. 본 증례에서는 전치가 정출되어 과개 교합을 보 이는 치주염 환자에서, 철저한 치주 치료와 하악 전치에 부착한 cute bracket과 골성 고정원을 이용한 고정원 보강으로 하악 전치의 양호한 압하 치료 결과를 얻을 수 있었으며, 8년간 경과 관찰하여 이를 보고하고자 한다.

(구강회복응용과학지 2021;37(1):48-60)

주요어: 치주염; 과개 교합; 치아 압하; 고정원

*교신저자: 최윤경

(49241) 부산시 서구 구덕로 179 , 부산대학교병원 치과진료센터 \& 의생명연구소

Tel: 051-240-7430 | Fax: 051-240-7706 | E-mail: youngyng@hanmail. net

접수일: 2021년 1월 14일 | 수정일: 2021년 2월 21일 | 채택일: 2021년 2월 23일 